Studia Oecumenica 17 (2017)

DOI: $10.25167 / \mathrm{SOe} / 17 / 2017 / 249-268$

ANDRZEJ A. NAPIÓRKOWSKI OSPPE

Wydział Teologiczny UPJPII

\title{
Eklezjotwórcza rola chrztu i Eucharystii w perspektywie teologii katolickiej i ewangelickiej
}

\author{
The Ecclesiastical Role of Baptism and Eucharist \\ in the Perspective of the Catholic and Evangelical Theology
}

\begin{abstract}
An ecclesiastical role of the two Sacraments, namely Baptism and Eucharist, has been presented with an ecumenical sensitivity in the perspective of Catholic and Protestant theology. The presentation of the Church and the Sacraments in the Medieval Catholic theology is the starting point of these considerations. Then we have sketched the discrepancies between the Roman theology in force at that time, and the postulates of the reformers in the XV and XVI century's tendencies for the renewal of the whole Church. The next part of the article focuses on the perspective of the Church and its connections with Baptism and the Eucharist in the original Lutheran doctrine. Further analysis is a presentation of the modern approaches of these connections in both Catholic and Protestant perspectives. The synthesis for this study is the common Baptismal and Eucharistic elements, which make up the ecclesiastical reality, despite of Sacramental differences in their understanding. Baptism and Eucharist make ecclesial unity. Thanks to this theoretical and theological reflection there is a clearer view of pastoral and practical possibilities of brining those two traditions of the divided Christianity of the West (Roman/Lutheran) closer.
\end{abstract}

Keywords: Ecumenism, the Church, sacramentality, baptism, Eucharist, Catholic tradition, Lutheran tradition, ecclesial unity.

\section{Streszczenie}

Z ekumeniczną wrażliwością ukazana jest eklezjotwórcza rola dwóch sakramentów, a mianowicie chrztu i Eucharystii w perspektywie tradycji katolickiej i protestanckiej. Punktem wyjścia jest prezentacja Kościoła i sakramentów w średniowiecznej teologii katolickiej. Następnie mamy naszkicowane rozbieżności między obowiązującą wówczas teologią rzymską a postulatami reformatorów w XV-i XVI-wiecznych nurtach odnowy całego Kościoła. Kolejna część artykułu zatrzymała się na ujęciu Kościoła i jego powiązań z chrztem i Eucharystią w pierwotnej doktrynie luterskiej. Dalsze analizy stanowi prezentacja już współczesnych ujęć omawianych związków tak u katolików, jak i protestantów. Synteza to wspólne elementy chrzcielne i eucharystyczne, jakie budują eklezjalną rzeczywistość, mimo sakramentalnej odmienności w ich rozumieniu. Chrzest i Eucharystia sprawiają bowiem kościelną jedność. Dzięki tej teoretyczno-teologicznej refleksji rysują się wyraźniej 
pastoralne i praktyczne możliwości zbliżenia dwóch tradycji (rzymskiej i luterańskiej) podzielonego chrześcijaństwa Zachodu.

Słowa kluczowe: ekumenizm, Kościół, sakramentalność, chrzest, Eucharystia, tradycja katolicka, tradycja luterska, kościelna jedność.

\section{Wprowadzenie}

Temat: „Eklezjotwórcza rola chrztu i Eucharystii w perspektywie teologii katolickiej i ewangelickiej” jest dość obszerny, stąd konieczność wprowadzenia pewnych ograniczeń metodologicznych i merytorycznych. Najpierw zaprezentujemy rozumienie Kościoła oraz sakramentów i ich wpływ na lud Boży według panującej średniowiecznej teologii katolickiej. Następnie przejdziemy do naszkicowania rozbieżności między obowiązującą wówczas teologią rzymską a postulatami reformy, jakie pojawiły się w wielu XV- i XVI-wiecznych nurtach dążących do odnowy Kościoła. Zawęzimy się tu naturalnie do kwestii eklezjalnych i sakramentalnych, według wskazań tematu. Później przejdziemy do ukazania rozumienia Kościoła i jego uwarunkowania przez chrzest i Eucharystię w łonie myśli reformatorów. Po tej części historycznej, skądinąd niezbędnej do uchwycenia i pogłębionego rozumienia rozwoju nauki o Kościele i sakramentach, kolejną część analiz poświęcimy aktualnemu pojmowaniu tych kwestii po stronie katolickiej oraz ewangelickiej. Całość prezentacji zwieńczy podsumowanie, gdzie ukażemy wnioski. Szanując konfesyjną tożsamość różnych chrześcijańskich Kościołów i podchodząc z ekumeniczną wrażliwością, wskażemy elementy chrzcielne i eucharystyczne tworzące rzeczywistość eklezjalną.

\section{Kościół i jego sakramenty w średniowiecznym papiestwie}

Od przełomu wiążącego się z panowaniem Konstantyna (272-337), kiedy doszło do utożsamienia państwa z Kościołem, a cesarz przejął kontrolę nad sprawami kościelnymi, powierzając jednocześnie zwierzchnikom Kościoła zarząd wielu kwestii państwowych, wolno mówić o Kościele jako chrześcijańskiej potędze. Swoje wyraźniejsze kształty polityczno-geograficzne zyskał on wprawdzie dopiero w utworzonym Państwie Kościelnym w 756 r., przesuwając na drugi plan rozumienie siebie jako charyzmatycznej wspólnoty. Biskupi stali się urzędnikami państwowymi z odpowiednimi prawami i insygniami. Papiestwo zaś otrzymało czytelne rysy cesarstwa. W pewnym stopniu ludzie rodzili się w Kościele, chrzest był obrzędem niejako to potwierdzającym. Już od swego początku człowiek był członkiem populus Dei, który z czasem stał się populus christianus. Kościół stał się militarnym imperium, gdzie zaczęła dominować polityczna władza. Wywo- 
łało to falę przeciwną, co trafnie oddają zarówno ruch monastyczny, jak i szereg prądów domagających się większej duchowości (paulicjanie, katarzy, albigensi czy bogomilcowie). Papież rościł sobie pretensje do władzy absolutnej, do podporządkowania cesarza, królów i książąt. On był origo, caput et radix wszelkiej władzy na ziemi. To zawężenie ujmowania Kościoła przyniosło wkrótce swoje skutki w eklezjologii. Dotąd to Eucharystia była pojmowana jako corpus Christi mysticum, a teraz weszło pojęcie corpus ecclesiae mysticum, redukujące Chrystusa do Kościoła. Podobnie zawężono termin laicus: wcześniej przez laików rozumiano cały ochrzczony lud, obecnie kler i hierarchia przestali być laikami. Dokonały się też przeobrażenia w zakresie sakramentu chrztu, który doznał kolejnego osłabienia poprzez wprowadzenie rozbudowanych rytów konsekracji kapłańskiej, biskupiej czy opackiej. Do rozumienia Kościoła jako imperium dobrze podprowadza również teoria tzw. dwóch mieczy, praktykowana już od Gelazego I (492-496). To Sedi Apostolicae Romanae powierzone zostały dwa miecze: duchowy oraz polityczny, przy czym mieczem duchowym posługiwał się sam papież, a miecz świata powierzał on cesarzowi i królom ${ }^{1}$.

Struktura organizacyjna średniowiecznego Kościoła doznała swoistego wstrząsu w trakcie sporu Innocentego III (1161-1216) z cesarzem Fryderykiem Barbarossą. W pontyfikacie tego papieża wolno widzieć szczytowy punkt cezaropapizmu. Od niego pochodzi oświadczenie, iż papież jest wprawdzie mniejszy od Boga, ale jest czymś większym od człowieka. Konflikt papiesko-cesarski spowodował ostatecznie zamianę włoskiej siedziby na Awinion (1378-1449), uzależniając tym samym papieży od władców Francji. Powszechnie znana jest ewangeliczna scena uspokojenia przez Chrystusa burzy nad Jeziorem Tyberiadzkim. Kiedy stolicę rzymskiego biskupa przeniesiono na południe Francji, na mozaice zdobiącej bazylikę św. Piotra Giotto di Bondone uwiecznił Chrystusowego Namiestnika na wstrząsanej nawałnicą barce. Papiestwo zatem w XIV w. przeniesione na siedemdziesiąt lat do Awinionu znajdowało się w poważnym kryzysie. Doszło do tego, iż na progu obrad Soboru w Konstancji w 1415 r. rywalizowało między sobą aż trzech papieży, tj. Grzegorz XII z Rzymu, Benedykt XIII z Avignonu i Jan XXIII z Pizy, a ojcowie soborowi dzielili się na zwolenników koncyliaryzmu i papalizmu (kurialistów)².

Jak Kościół sam siebie rozumiał i definiował w okresie XII-XVI w.? Obraz Kościoła jako Imperatrix et Domina mocno oddziaływał na całą eklezjologię i sakramentologię. Doszło do redukcjonistycznego utożsamienia Kościoła z hierarchią, gdzie wszyscy inni byli jej poddanymi. W tej przede wszystkim feudal-

${ }^{1}$ Por. H. DörIng, Grundriß der Ekklesiologie, Darmstadt 1986, 55-56.

${ }^{2}$ Szerzej o tym piszę w części mojej eklezjologii, gdzie zajmuję się historią Kościoła średniowiecznego: por. A.A. NAPIÓRKOwsKI, Bosko-ludzka wspólnota. Podstawy katolickiej eklezjologii integralnej, Kraków 2010, 175-185. 
nej, a nie hierarchiczno-sakramentalnej, wizji Kościół powszechny pojmował się jako Kościół papieski. Kanonista Egidiusz Romanus (1244-1316) będzie mógł nawet napisać: papa qui dici ecclesia. Zresztą temat Kościoła funkcjonował przede wszystkim w kanonistyce ${ }^{3}$.

Dla całości obrazu należy jednak przywołać myśl przeciwną, gdyż obok motywu imperium funkcjonował też motyw mysterium. A zatem nie w kanonistyce, lecz przede wszystkim w wielkich sumach teologicznych tego okresu była mowa o Kościele jako ciele i oblubienicy Chrystusa. Godnymi uwagi nie są tylko traktaty Dunsa Szkota, Alberta Wielkiego, Tomasza z Akwinu czy Bonawentury, lecz także wspomnianego Egidiusza z Rzymu De ecclesiastica sive summi pontificis potestate z 1301 r., Jakuba z Viterbo De regimine christiano z 1302/1303, Jana z Raguzy Tractatus de Ecclesia z 1433-1435 r. czy Jana Torquemady Summa de Ecclesia z 1453 r., traktujące wyłącznie o Kościele.

Wielcy mistycy tego czasu zwracali uwagę nie tyle na instytucjonalność i przedmiotowość w Kościele, co na właściwe życie duchowe we wierze, nadziei i miłości. I mimo iż w pierwszej linii Kościół Chrystusowy był dla nich wspólnotą świętych, a spojrzenie ich wykraczało poza jego widzialne granice, to jednak sama z siebie rodziła się krytyka konkretnego Kościoła. Często obracało się to w myśl o ecclesia spirituals - duchowy, ukryty, niewidzialny Kościół. Tak ujmuje to Joachim z Fiore (1130/35-1202), pisząc o Kościele przyszłości. Z kolei Franciszek z Asyżu (1182-1226) swoim życiem pokaże, iż to nie władza, bogactwo czy panowanie określają Kościół, ale czynienie pokuty, ubóstwo i gotowość ofiarnej służby. Bez ówczesnych ruchów zakonnych (zakony żebracze) oraz powstających wraz z nimi tzw. świeckich drugich i trzecich zakonów obraz Kościoła tamtej doby staje się niepełny. Obok artystycznych wyobrażeń Chrystusa jako władcy, króla i sędziego pojawia się przecież mistyka pasyjna, gdzie cierpiący i ukrzyżowany Pan jest obrazem Kościoła i zależnej od tego eklezjologii (Henryk Suzo z Konstancji, Jan Tauler, Mistrz Eckhart, Bernard z Clairvaux). Zdecydowaną krytykę konkretnego Kościoła i jego struktur podjęli m.in. Dante Alighieri, Marsyliusz z Padwy czy Wilhelm Ockham ${ }^{4}$.

Średniowieczny obraz Kościoła nie jest zatem mało rozwinięty czy monolityczny. Jest to z pewnością rzeczywistość złożona i zróżnicowana. Wydaje się, iż dlatego pojęcie Mikołaja Kuzańczyka complexio oppositorum, jakie odnosił on do Boga, można zastosować również i eklezjologicznie.

\footnotetext{
${ }^{3}$ Por. H. DörInG, Grundriß der Ekklesiologie, 57.

${ }^{4}$ Por. tamże, 57-58.
} 


\section{Istota sporów u początków nowożytności}

Wiele elementów u początku nowożytnego czasu wpłynęło na podjęcie śmiałych zmian w Kościele. Wynikały one z nowych odkryć geograficznych, zmian w świadomości społecznej, dążenia do większej samodzielności poszczególnych warstw w feudalnej strukturze (zakony, rycerze czy rzemieślnicze cechy). Universalitas christiana doznawała wstrząsów z strony licznych odśrodkowych tendencji partykularnych. Renesansowe umiłowanie sztuki, poezji i filozofii rozbudziło wolność myślenia i dowolność gustów, a humanizm ożywił zainteresowanie człowiekiem. Postęp matematyczny i eksperymenty (Galileusz, Mikołaj Kopernik) dowartościowały osiągnięcia jednostki.

W stronę skorumpowanego Kościoła papistów popłynął z zewnątrz szeroki strumień postulatów domagających się reformy. Jednak już z wnętrza kościelnej społeczności wysuwano żądania radykalnych przemian, poczynając od angielskiego duchownego Johna Wiklifa (1329-1384) czy czeskiego księdza Jana Husa (1370-1415). Z tymi oboma uniwersyteckimi profesorami, jak też i z ich dziełami, hierarchia obeszła się ostatecznie wyjątkowo haniebnie. Przeciwko Wiklifowi papież Grzegorz XI (1331-1378) wydał aż pięć bulli potępiających, a na polecenie papieża Marcina V, wybranego na konklawe w Konstancji w listopadzie 1417 r., angielski biskup w 1428 r. wyjął kości Wiklifa z grobu na cmentarzu w Lutterworth, nakazując je zmiażdżyć, spalić i wrzucić popiół do rzeki Swift. Nie lepiej potraktowano Jana Husa, którego - mimo „listu żelaznego” od króla Zygmunta Luksemburskiego - potępiono i skazano, a ostatecznie 6 lipca 1415 r. w czasie obrad Soboru w Konstancji spalono na stosie.

A zatem już na sto lat przed wystąpieniem Marcina Lutra (1483-1546) chrześcijańscy reformatorzy proponowali zasadnicze zmiany doktrynalne, sięgające ustroju Kościoła i jego sakramentów. Jakkolwiek w powszechnej świadomości za początek protestantyzmu przyjmuje się 95 tez zawartych w piśmie Disputatio pro declaratione virtutis indulgentiarum (Propositiones wider das Ablas), które wyszło spod ręki Lutra w 1517 r., to jednak wypada zauważyć dość odmienną wizję Kościoła i sakramentów, jaką proponowali właśnie owi prekursorzy Reformacji. Istota sporów znajdowała się w ujmowaniu sakramentalności, czyli odrzucono sakrament bierzmowania, spowiedzi, namaszczenia chorych, święceń i małżeństwa ${ }^{5}$. Przyjęto chrzest oraz Wieczerzę Pańską, negując w niej realną obecność Chrystusa (transsubstancjacja) i jej charakter ofiarniczy. Ognisk kontrowersji było naturalnie znacznie więcej. Dotykały one ponadto takich zagadnieniach, jak: grzech pierworodny, wolna wola, zasługująca wartość zbawcza

\footnotetext{
5 Por. J. Podzielny, Godność powołania matżeńskiego w ujęciu Marcina Lutra, „Studia Oecumenica" 9 (2009), 151-157.
} 
dobrych uczynków, predestynacja, pokuta - spowiedź, nieomylność i autorytet soboru oraz papieża, wyższość soboru (koncyliaryzm) nad papieżem, kult świętych, czyściec czy śluby zakonne.

Skąd to wynikało? Było to konsekwencją zasad, jakie przyjęła Reformacja. Przesłanki reformacji mijały się z ówczesnym systemem dedukcji. Nie korespondując ze statycznie ujmowaną rzeczywistością stworzeń, proponowały teologię mniej spekulatywną. Reformacja opowiadała się raczej za większym zauważeniem dramatu człowieka, grzechu i darmowej łaski, za analizą ludzkiej egzystencji, wynikającej z totalnego zniszczenia natury ludzkiej. Teologię Lutra wolno sprowadzić do jednego przedmiotu rozważań. Jest nim „Bóg przynoszący usprawiedliwienie" (der rechtfertigende Gott) oraz „człowiek jako grzesznik” (der Mensch als Sünder $)^{6}$. Postulaty Lutra wzywały do przedziwnej permanentnej pokuty?

Nauka wszystkich reformatorów była nade wszystko umocowana biblijnie. Zasady sola scriptura, sola fide, sola gratia et solus Christus wytyczyły kierunek i rozwój nowej teologii ${ }^{8}$. W ich świetle ujęto na nowo rozumienie Kościoła oraz jego sakramentów. Eklezjologia poczęła w usprawiedliwieniu widzieć swoje naczelne kryterium. Ewangelicy głosili, iż usprawiedliwienie „stoi i upada” wraz z całym Kościołem (articulis stantis et cadentis ecclesiae) ${ }^{9}$. Od wierności kryterium usprawiedliwienia zależy luterańska teologia, cały Kościół i jego życie i ewangelizacja. Artykuł $O$ usprawiedliwieniu to podstawowe narzędzie krytyczne całej eklezjologii. W Artykułach Szmalkaldzkich Luter napisze: „Pierwszym

${ }^{6}$ Por. A.A. NAPIóRKowski, Usprawiedliwienie grzesznika, Kraków 1998, 88-99.

${ }^{7} \mathrm{~W}$ ostatnich latach pojawiły się próby thumaczenia tej pełnej zadziwiającego lęku wobec Boga postawy Lutra poprzez odwołania do psychologii. Erik Erikson postuluje dotarcie do osoby niemieckiego reformatora w świetle konfliktu ojciec - syn (zob. E.H. ERIKSON, Der junge Mann Luther. Eine psychoanalitische und historische Studie, Frankfurt am Main 1975). Tezy Eriksona zostały po większej części przezwyciężone, por. H. SchILling, Marcin Luter. Buntownik w czasach przełomu, Poznań 2016, 9-15. Z kolei Dietrich Emme przedstawia osobę Lutra jako tego, który w początkowym okresie swoich prawniczych studiów w niefortunnym pojedynku zabił swoich przeciwników. Według Emmego wyrzuty sumienia, spowodowane popełnioną zbrodnią, miały skłonić młodego Lutra do szukania azylu w murach augustiańskiego klasztoru, zob. D. EMME, Martin Luter. Seine Jugend- und Studienzeit, Regensburg 1981. W teologii Lutra odnajdujemy wiele interesujących przesłanek, jak i sporo elementów domagających się krytyki. Trudno bowiem zaakceptować jego wezwania do wygnania Żydów z Saksonii, do spalenia synagog, do odebrania pieniędzy pochodzących z lichwy. Choćby tylko te elementy jego myślenia dopuszczają również krytyczne spojrzenie na jego dorobek.

${ }^{8}$ Por. L. GRAne, Wyznanie augsburskie. Wprowadzenie w podstawowe myśli Reformacji luterańskiej, Bielsko-Biała 2002, 53-64, 75-83, 151-157, 182-196; G. SAUTER, Podstawowe pytania wiary, Bielsko-Biała 1997, 121-140; M. Uglorz, Marcin Luter. Ojciec Reformacji, Bielsko-Biała 1995, 137, 140-144; TeNże, Zarys nauki Kościoła luterańskiego, w: J. Below, M. Legendź (red.), Świadectwo wiary i życia. Kościót luterański w Polsce wczoraj i dziś, Bielsko-Biała 2004, 42-45; zob. F. LaU, Marcin Luter, Warszawa 1966, 235 (cz. I: F. LAU, Marcin Luter; cz. II: O. Bartel, J. NARZYŃSKI, Marcin Luter w Polsce).

${ }^{9}$ Więcej u: A.A. NAPIÓRKowsKI, Bogactwo łaski a nędza grzesznika. Zróżnicowany konsensus teologii katolickiej i luterańskiej o usprawiedliwieniu osiągnięty w dialogu ekumenicznym, Kraków 2011², 31-101. 
i głównym artykułem jest to, że: Jezus Chrystus, Bóg i Pan nasz, umarł z powodu grzechów naszych i zmartwychwstał dla usprawiedliwienia naszego ( $R z$ 4,25). (...) Od tego artykułu odstąpić lub coś przeciwnego uznawać czy dopuszczać nikt z nabożnych nie może, choćby niebo, ziemia i wszystko zawalić się miało. «Nie ma bowiem żadnego innego imienia danego ludziom, przez które moglibyśmy być zbawieni»-powiada Piotr w Dziejach Apostolskich 4,12. «I przez Jego rany jesteśmy uzdrowieni» (Iz 53,5). Na tym też artykule zasadza się i opiera wszystko, czego przeciwko papieżowi, diabłu i całemu światu w naszym życiu nauczamy, świadczymy i czynimy. Dlatego powinniśmy co do tej nauki mieć pewność i bynajmniej nie powątpiewać, w przeciwnym razie sprawa jest całkowicie przegrana, i papież, i diabeł, i wszystko, co nam przeciwne, wygrywają i odnoszą nad nami zwycięstwo"10.

Protestancka teza o nadrzędności usprawiedliwienia wobec Kościoła wynikała z potrzeby wykształcenia takiej hermeneutyki, która znalazłaby się poza oficjalnie obowiązującym systemem rzymskim. Papiestwo z jego nadużyciami moralnymi i dyscyplinarnymi mogło tylko wtedy doznać reformy, jeśli wróci się do samych źródeł Objawienia. Dlatego usprawiedliwienie nie może stanowić zaledwie pewnego elementu nauki reformacyjnej, lecz jest jego centrum i granicą. Usprawiedliwienie to kryterium regulujące. Podobnie i Jan Kalwin w dziele Institutio Christianae Religionis wyzna, iż usprawiedliwienie to decydujący punkt zawieszenia całej wiary chrześcijan. Reformator z Genewy powiąże usprawiedliwienie z uświęceniem i tym samym dowartościuje wymiar pneumatologiczny przez całkowite uzależnienie możliwości nowego chrześcijańskiego życia od działania Ducha Świętego ${ }^{11}$.

Dokonując egzegezy Pawłowego Listu do Rzymian, reformatorzy przyjęli inne rozumienie usprawiedliwienia niż strona papieska. Dla przedstawicieli odnowy usprawiedliwienie jest przede wszystkim darmową łaską, którą grzesznik nie jest w stanie sobie wysłużyć. Dobre uczynki chrześcijanina nie mają wartości zasługującej w perspektywie zbawczej. Winny one być skutkiem miłości i wdzięczności człowieka wobec Boga. Jeśli uczynki przynosiłyby zbawienie, to oznaczałoby, iż człowiek sam siebie zbawia, a Chrystus umarł za darmo. Oznaczałoby to, iż wypełnianie Prawa przynosi człowiekowi zbawienie. A to przecież jest judaizm, a nie chrześcijaństwo. Tym samym reformatorzy wystąpili zdecydowanie wobec kupczenia odpustami i innymi dobrami zbawczymi.

${ }^{10}$ M. Luter, Artykuty Szmalkaldzkie, cz. II, art. I..

${ }^{11}$ Por. P. JASKóŁA, Usprawiedliwienie i uświęcenie wedlug Jana Kalwina, w: TENŻE (red.), Ekumenizm na progu Trzeciego Tysiaclecia, Opole 2000, 297-309. 


\section{XV- i XVI-wieczna koncepcja Kościoła reformatorów}

Spośród wielu nurtów reformacyjnych trudno wyprowadzić spójną i dopracowaną koncepcję eklezjologiczną, gdyż po większej części postulowane zmiany miały raczej charakter krytyki. Z czasem jednak z pism reformatorów zaczął się wyłaniać odrębny obraz Kościoła w stosunku do obowiązującego po stronie rzymskiej. Mimo ewolucji pojęcia Kościoła, Luter przyjmował jego konieczność do zbawienia. Ze studium Konfesji Augsburskiej i Apologii Konfesji Augsburskiej $^{12}$ można wyprowadzić przekonanie o stopniowym kształtowaniu się poglądu, iż zewnętrzny, widzialny i instytucjonalny wymiar Kościoła pozostaje w sprzeczności z jego duchowym, prawdziwym wymiarem, zaciemniając zwiastowanie Ewangelii ${ }^{13}$.

Reformatorzy nie mogli się zatem zgodzić na dalsze przejawy cezaropapizmu. Do ich przekonań w żaden sposób nie przystawało rzymskie rozumienie Kościoła jako „najwyższej zewnętrznej monarchii całego świata, w której rzymski biskup powinien mieć nieograniczoną władzę, o której nikomu nie wolno by dyskutować, ani jej osądzać - czytamy w Obronie Wyznania Augsburskiego władzę ustanawiania artykułów wiary, podważania Pism świętych według swej woli, ustanawiania form kultu lub ofiar, podobnie też ogłaszania ustaw według swej woli, uwalniania od nich i znoszenia ich według swej woli - władzę dotyczącą zarówno praw boskich, jak i kanonicznych czy świeckich. Od niego [papieża] cesarz i wszyscy królowie otrzymywaliby swoją władzę i prawo dzierżenia władztw z polecenia Chrystusa, któremu Ojciec wszystko poddał, stąd należy rozumieć, że prawo to przeniesione zostało na papieża"14.

Dla M. Lutra, J. Kalwina czy H. Zwingliego Kościół to niewidzialne zgromadzenie prawdziwie wierzących (sanctorum communio) w Ewangelię Chrystusową. Z kolei w swojej widzialności Kościół tworzą grzesznicy. Zauważają, iż wielu obłudników ma z nimi wspólnotę zewnętrznych znaków i że są oni członkami Kościoła według wspólnoty zewnętrznych znaków ${ }^{15}$. Reformatorzy pojmowali Kościół jako wspólnotę zebraną wokół wydarzenia Słowa i sakramentów. „Atoli Kościół nie jest tylko wspólnotą rzeczy zewnętrznych albo obrzędów, jak inne instytucje polityczne - piszą autorzy Obrony Wiary Augsburskiej - lecz w zasadzie jest wspólnotą wiary i Ducha Świętego w sercach; wspólnotą, która jednak ma zewnętrzne znamiona, aby można było ją poznać, mianowicie znamionami

${ }_{12}$ Zob. Księgi wyznaniowe Kościoła luterańskiego, Bielsko- Biała 1999.

${ }_{13}$ Zob. P. JaskóŁA, Wyznania chrześcijańskie bez jedności z Rzymem, Opole 2008.

${ }^{14}$ Artykuł VII i VIII. O Kościele. Obrona Wyznania augsburskiego, w: Księgi wyznaniowe Kościoła luterańskiego, 229.

15 Por. Obrona Wyznania augsburskiego, w: Księgi wyznaniowe Kościoła luterańskiego, 230. 
tymi są czysta nauka Ewangelii i sprawowanie sakramentów zgodnie z Ewangelią Chrystusową"16.

Ruch społeczno-religijny, ogarniający XVI-wieczną Europę, był nade wszystko buntem przeciwko potężnej kościelnej instytucji, uosabianej przez widzialne papiestwo. Dlatego katolicy, dążący do odnowy Kościoła, opowiadali się za Kościołem ukrytym, który nie jest związany z określonym miejscem, czasem czy osobą ${ }^{17}$. Kościół to nade wszystko duchowa wspólnota wiary i Ducha Świętego, posiadająca zewnętrzne znamiona, którymi są czysta nauka Ewangelii i sprawowanie sakramentów zgodnie z Ewangelią Chrystusową ${ }^{18}$. Toteż w świetle nauczania reformatorów trzeba odejść od przypisywania sakramentalności Kościołowi i jego wielu sakramentom. Teologia katolicka głosiła, iż zbawienie osiąga się, przynależąc do Kościoła jako medium gwarantującego Bożą łaskę. Luter wypracował bardziej osobistą, indywidualną soteriologię. Metafizycznie rozumiana rzeczywistość, jaką przedkładała scholastyka, została zastąpiona relacją grzesznika z usprawiedliwiającym Bogiem.

Postawienie w centrum reformacyjnej refleksji kryteriologicznej funkcji usprawiedliwienia z wiary dopuszczało zatem odrzucenie instytucjonalności Kościoła jako niezbędnego pośrednika zbawienia ${ }^{19}$. Odtąd wolno było mówić o relacji między Bogiem a człowiekiem. Artykuł o usprawiedliwieniu wskazywał na bezwarunkowość łaski i jej niezależność od działań człowieka. Usprawiedliwieni jesteśmy bowiem darmo, nie z naszych dobrych uczynków, odpustów, postów czy też dzięki istnieniu papiestwa. Nie legalistyczne pośrednictwo rzymskiego Kościoła jest gwarantem zbawienia, ale darmowa łaska Chrystusa, która dosięga nas przez wiarę w tajemnicy chrztu i Wieczerzy Pańskiej. Nauka o usprawiedliwieniu nakazywała zatem, aby wręcz przeciwstawić się Kościołowi jako instytucji zagrażającej darmowości łaski. Doszło zatem do odrzucenia sakramentalności Kościoła, ale nie jego instytucjonalności ${ }^{20}$.

Dla Lutra Kościół zachowuje zatem swoją strukturę instytucjonalną ${ }^{21}$, lecz nie w katolickim rozumieniu hierarchię. Do jej charakterystycznych cech wittenberski reformator zaliczał posługiwania kościelne, spełniane przez biskupów,

16 Tamże, 226.

${ }_{17}$ Por. R. Porada, Kościót i apostolskość Kościoła w nauczaniu Marcina Lutra, „Studia Oecumenica" 1 (2001), 173-174.

18 Por. Artykuł VII i VIII. O Kościele, 226.

19 Reformacja definiowała Kościół jako wspólnotę wierzących, skupioną wokół Słowa i Sakramentu. Luter odmawiał zbawienia również i tym protestantom, którzy odrzucali jego pojmowanie Eucharystii (Zwingli), czy chrztu (anabaptyści).

${ }^{20}$ Por. R. Porada, Kościół i apostolskość Kościoła w nauczaniu Marcina Lutra, 175.

${ }^{21}$ Ten porządek organizacyjny tworzą wszyscy ochrzczeni, gdyż Luter podkreśla powszechne kapłaństwo wszystkich wierzących. Z nich wybierani są kapłani, którzy są delegowani do zwiastowania Słowa Bożego w kazaniu i sakramencie. 
proboszczów i kaznodziejów. Według niego mieli oni spełniać cztery zadania: przepowiadać Słowo, sprawować chrzest i Wieczerzę Pańską oraz wykonywać władzę kluczy. Konieczność istnienia urzędu (ministerium) w Kościele uzasadniał Luter podwójnie: 1) domaga się tego sam kościelny porządek, gdyż tylko jedna osoba w imieniu Kościoła może spełniać określoną funkcję; 2) jest on ustanowiony przez Chrystusa.

\section{Chrzest i Eucharystia i ich kościelnotwórcza funkcja w świetle ewangeli- ckim}

Luterańska nauka o sakramentach, odwołując się do podstawowych zasad Reformacji, zaakcentowała szczególnie solum Verbum, co rozumiano, iż Bóg udziela swego Ducha, a wraz z Nim zbawczych darów poprzez zewnętrzne Słowo w kazaniu i sakramencie ${ }^{22}$. Według niej należało odrzucić to wszystko, co nie ma wyraźnego potwierdzenia w Piśmie Świętym. Stosując się do przyjętych założeń, konsekwentnie odrzuciła ona sakramentalne ujęcie bierzmowania, pokuty, małżeństwa, kapłaństwa i namaszczenia chorych.

A zatem wolno przyjąć jedynie te sakramenty, które spełniają trzy warunki: 1) sakrament musi być jednoznacznie potwierdzony biblijnie, słowami samego Jezusa (ipso Christo instituta); 2) musi być „obietnicą” (promissio) odpuszczenia grzechów człowiekowi; 3) musi być znakiem (signum) potwierdzającym ważność i autentyczność obietnicy. Słowa obietnicy (testimonia gratiae et remissionis peccatorum) stanowią testament Jezusa. Kierując się tymi przesłankami, reformatorzy przyjęli zaledwie dwa sakramenty, a mianowicie chrzest oraz Wieczerzę Pańską, gdyż pozostałe nie mają koniecznych wyznaczników, jakimi są: institutio, promissio i signum ${ }^{23}$.

Interesujący wątek odnośnie do sakramentalności wniosła dysputa między Lutrem a królem Henrykiem VIII. Angielskiemu monarsze chodziło o zwalczenie błędnej nauki, jaka m.in. odbierała człowiekowi mysterium w religii. Ogłoszenie w 1520 r. przez niemieckiego reformatora pisma pt. O niewoli babilońskiej Kościoła (De Captivitate Ecclesiae Babylonica) spowodowało odpowiedź króla już w 1521 r. pt. Assertio septem sacramentorum Lutheri. Henryk broni katolickiej nauki o sakramentach i wylicza wszystkie siedem oraz przesyła swoją rozprawę ówczesnemu papieżowi. Leon $\mathrm{X}$ oczywiście traktat królewski przyjmuje i władcę Anglii nagradza tytułem Fidei Defensor. Jakkolwiek król był doskonale wykształcony, ale raczej jako humanista niż teolog, stąd najprawdopodobniej

\footnotetext{
${ }^{22}$ Por. Wyznanie Augsburskie, art. V; Artykuty Szmalkaldzkie, cz. III, art. VIII.

${ }^{23}$ Por. P. KopIEc, Instytucja matżeństwa a sakramentologia luterańska, RTK 55 (2008) 7, 174.
} 
przy redakcji tego traktatu brali udział kanclerz królewski Tomasz More oraz arcybiskup Yorku, Edward Lee ${ }^{24}$.

Poza Aktem Supremacji z 1534 r., ogłaszającym króla jedyną i najwyższą głową Kościoła Anglii, w tamtejszej Reformacji brak przełomowych zmian czy też takich sztandarowych teologów, jak Luter bądź Kalwin, co pozwalałoby mówić o narodzinach anglikanizmu. Reformacja na Wyspach rozgrywała się pomiędzy staraniami Henryka VIII, dążącego do uzyskania papieskiej nieważności swego małżeństwa z Katarzyną i zawarcia nowego z Anną Boleyn, a antyklerykalnymi tendencjami społeczeństwa angielskiego. Tamtejszą Reformację należy widzieć bardziej jako proces oscylujący między ortodoksją katolicką a umiarkowanym obliczem protestantyzmu, inspirowanym niemieckimi postulatami. Doktrynalne treści anglikanizmu zawierają właściwie trzy źródła pisane: Common Prayer Book opublikowane w 1549 r., XXXIX Artykutów z 1563 r. i Treatise on the Lawes of Ecclesiastical Politie Richarda Hookera z 1594 r. W sensie ścisłym Kościół anglikański uznaje dwa sakramenty, a mianowicie chrzest oraz Eucharystię. Im obu przypisuje poważne znaczenie kościołotwórcze ${ }^{25}$.

Niemieckojęzyczni chrześcijanie dążący do odnowy przypisali Ewangelii podwójną funkcję. Po pierwsze, stała się kryterium weryfikującym ilość sakramentów, a po drugie - nadającym sakramentowi treść. Teoria sakramentologiczna wypracowana przez Lutra i Melanchtona, bazując na koncepcji św. Augustyna oraz scholastycznej, głosiła, iż sakrament posiada strukturę znakową. Znak sakramentu tworzą słowo i materia. To słowo przemienia materię (element zewnętrzny) w to, co jest sakramentem. Decydujące jest słowo (obietnicy). Dlatego Kościół, który jest tworzony przez słowo (creatura verbi), urzeczywistnia się dzięki dynamice sakramentów, sam w żadnym wypadku nie będąc sakramentem. Jedynie przez chrzest i Eucharystię udzielana jest człowiekowi Boska łaska, wprowadzająca go w rzeczywistość eklezjalną, gdzie realizuje się ekonomia zbawcza. Odbiór sakramentalnej łaski dokonuje się nie sam z siebie - jak nauczał Rzym w formule ex opere operato - lecz dzięki wierze człowieka. Sakramenty nie skutkują swoją własną mocą. Tym samym w luterańskiej sakramentologii doszedł do głosu radykalny fideizm.

Z treści Ksiąg Wyznaniowych dowiadujemy się, iż jakkolwiek sakramenty pełnią funkcję eklezjotwórczą, to jednak nie w takim stopniu, jak to utrzymuje teologia rzymska. Reformatorzy wyznają, że ,sakramenty nie tylko są znamionami wyznania wśród ludzi (i znakami rozpoznawczymi między ludźmi), jak zmyślają niektórzy (na przykład w odniesieniu do haseł czy zawołań w obozie wojennym,

${ }^{24}$ Zob. S. AppeL, „König Heinz und Junker Jörg”. Heinrich VIII. gegen Luther gegen Rom, Darmstadt 2016.

${ }^{25}$ Por. P. Kopiec, Eschatologia anglikańska, „Roczniki Teologii Ekumenicznej” 3 (2011), $133-149$. 
czy do barw szat dworzan), lecz są raczej znakami i świadectwami woli Bożej wobec nas, którymi Bóg skłania serca do wierzenia"26. To od indywidualnego nastawienia wierzącego zależy, na ile on doświadcza zbawienia.

Dokonując zdecydowanej krytyki katolickiej sakramentologii, reformatorzy głosili niesakramentalność małżeństwa. Zagadnienie małżeństwa w pismach reformatorów zostało wyczerpująco opracowane przez ks. prof. Piotra Jaskółę z ekumeniczną subtelnością ${ }^{27}$. Małżeństwo było stanem ustanowionym, nakazanym i błogosławionym przez Boga, ale pozbawionym znaku łaski. Jest ono „rzeczą świecką". Podobnie Luter krytykował celibat i śluby zakonne ${ }^{28}$.

Luter odrzucał też rzymskie rozumienie pokuty. Pisze: „Jest rzeczą niemożliwą, aby papiści prawidłowo nauczali o pokucie, skoro nie pojmują grzechu. Nie pojmują prawidłowo grzechu pierworodnego, gdyż mówią, iż naturalne siły człowieka pozostały nienaruszone i nieskażone i że rozum może prawidłowo nauczać, i że wola potrafi wykonywać to, co jest nauczane, i że Bóg na pewno obdarza swoją łaską, gdy człowiek czyni według wolnej woli tyle, na ile go stać" 29 .

Rygorystyczne rozróżnienie między ekonomią stworzenia a ekonomią zbawienia zmusiło reformatorów do odrzucenia rzymskiego pojęcia sakramentalności i ostatecznie pozwoliło na przyjęcie jedynie dwóch sakramentów: chrztu i Eucharystii, gdyż tylko one spełniają warunki, które czynią je sakramentami. I to one budują Kościół, który wzrasta też przez krzyż, zwiastowanie Ewangelii i przez modlitwę.

\section{Współczesna katolicka eklezjologia i sakramentologia}

Sobór Trydencki, odrzucając pojęcie Kościoła lansowane przez wczesnych reformatorów, czyli Johna Wiklifa (1320-1384) $)^{30}$ i Jana Husa (1369-1415) ${ }^{31}$, opowiedział się wyraźnie za widzialnością Kościoła i jego sakramentalnością. Jakkolwiek ten Sobór nie ogłosił odrębnego traktatu o Kościele, to jednak studiując jego dekrety o wzajemnym stosunki Pisma Świętego i Tradycji oraz o wzajemnej relacji Pisma Świętego i Kościoła w odniesieniu do interpretacji Biblii i podkreśleniu sensu Pisma, dalej: nauki o usprawiedliwieniu oraz o łasce, można

26 Obrona Wyznania Augsburskiego, w: Księgi wyznaniowe Kościoła luterańskiego, 262.

27 Zob. P. JASKÓŁA, Problem matżeństwa w relacjach ewangelicko-rzymskokatolickich. Historia i perspektywy nowych rozwiązań, Opole 2013.

${ }_{28}$ Por. tamże, 48-59.

29 M. LuTER, Artykuły Szmalkaldzkie, cz. III, art. III, nr 10.

${ }^{30}$ Por. DS 1121-1139.

31 Por. DS 1201-1230. 
wyprowadzić ważkie konsekwencje dla ujęcia Kościoła. Jeśliby to wszystko zostało powiedziane w taki sposób przed Reformacją, najprawdopodobniej by do niej nie doszło. Jednakże poreformacyjny obraz Kościoła został określony przede wszystkim jako antyreformacyjny ${ }^{32}$.

Do dziś bellarminowska definicja Kościoła z XVI w. uległa wielokrotnemu i dość poważnemu przepracowaniu. Aktualne rozumienie Kościoła jest wynikiem uchwał Drugiego Soboru Watykańskiego i osiągnięć teologii posoborowej. Jak dzisiaj rozumie się Kościół? Jakkolwiek do eklezjologii katolickiej kluczem jest ujęcie sakramentalne, to jednak odnajdujemy w niej sześć kategorii, które przybliżają nam mysterium Ecclesiae. Takie kategorie, jak: lud Boży, Mistyczne Ciało Chrystusa, świątynia Ducha Świętego, wspólnota i sakrament podstawowy, wzajemnie się nie wykluczają, ale raczej uzupełniają. Rzeczywistość Bosko-ludzka jest zbyt bogata, aby mogła być wyrażona tylko jedną kategorią. Te kategorie są kongruencyjne, a zatem wskazują na te elementy kościelne, które są nieobecne w innych. W ostatnich latach teolodzy katoliccy z pewną predylekcją używają kategorii „wspólnota”.

W swojej książce Kościót jako sakrament zbawienia Y. Congar wskazuje na trzy powody, które spowolniały wykształcanie się idei Kościoła jako sakramentu. Po pierwsze, francuski teolog wymienia nauczanie św. Augustyna, który kładł nacisk na rolę znaku przy określeniu sakramentu, oddzielając aspekt objawionej treści od aspektu obrzędowej czynności. Po drugie, traktat o sakramentach wypracowywano bez łączności z eklezjologią. Po trzecie, średniowieczne chrześcijaństwo istniało bez łączności ze „światem”. Rozwiązaniem jest odkrycie chrystologicznych podstaw sakramentu, co dokonało się w niemieckiej teologii w XIX w. (J.E. Kuhn, J.H. Oswald, M.J. Scheeben) ${ }^{33}$. Kościoła nie należy rozumieć jako jednego z siedmiu sakramentów, jakie zostały w nim złożone, lecz jako sakrament podstawowy. Z kolei w XX w. - dzięki pracom takich teologów, jak O. Semmelroth, K. Rahner, P. Smulders, W. Willems, E. Schillebeeckx - dokonało się odejście od prawniczego i zewnętrznego ujęcia Kościoła. Podkreślając inkarnacyjny charakter łaski, zaczęto sakramenty widzieć jako zewnętrzną postać dobrowolnego udzielania się Boga i odnosić to zwłaszcza do Kościoła. H.U. von Balthasar opisze Kościół jako Ursakrament w swoim oblubieńczym zjednoczeniu z Chrystusem, a Schillebeeckx, że na tym świecie jest on ziemskim sakramentem uwielbionego Chrystusa ${ }^{34}$.

Podejmując refleksję nad poszczególnymi sakramentami, O. Semmelroth, E. Schillebeeckx czy K. Rahner jednomyślnie oświadczają, iż pierwszym skutkiem sakramentu jest rzeczywistość eklezjologiczna, gdyż jest to wejście do eu-

\footnotetext{
32 Por. H. DöRING, Grundriß der Ekklesiologie, 60.

${ }_{33}$ Por. Y. Congar, Kościót jako sakrament zbawienia, Warszawa 1980, 58-60.

${ }^{34}$ Por. tamże, 65.
} 
charystycznej wspólnoty przymierza. Głębsze włączenie do jedności Ciała Mistycznego Chrystusa stanowi res et sacramentum w tym sakramencie. Chodzi zatem tak o dowartościowanie wspólnoty wiernych sprawujących Eucharystię, jak znaczenie rzeczywistej obecności Chrystusa wydanego za nas. W katolickiej perspektywie chrzest i Eucharystia są szczególną i wyjątkową aktualizacją działania Kościoła jako pierwszego, głównego i ogólnego sakramentu.

Oficjalne odejście od jurydycznego obrazu Kościoła i samookreślenie siebie jako ludu Bożego, jako wspólnoty, miało miejsce w urzędowych dokumentach Drugiego Soboru Watykańskiego. Odkrywanie Kościoła jako tajemnicy komunii widać w Lumen gentium i Gaudium et spes, ale też w encyklice Pawła VI Ecclesiam suam $(1964)^{35}$.

Znaczący wpływ na rozpowszechnienie obrazu Kościoła jako wspólnoty miał Synod Biskupów w 1985 r., który w swoich końcowych uchwałach wręcz nakazał posługiwanie się takim pojęciem. Ten nadzwyczajny Synod Biskupów, zwołany w 20. rocznicę zakończenia obrad Drugiego Soboru Watykańskiego, wypracował dość przejrzystą charyzmatyczno-instytucjonalną strukturę Eklezji. Trzy pojęcia dobrze to oddają, a mianowicie: mysterium - communio - missio. Kładąc nacisk na ujęcie Kościoła jako wspólnoty, ojcowie synodalni ukazali Kościół jako sakramentalną wspólnotę Boga z człowiekiem, która musi się realizować w misji ${ }^{36}$.

Określenie Kościoła jako communio znalazło swoje potwierdzenie i dopracowanie w następnym dokumencie, jaki opuścił Kongregację Nauki Wiary. W piśmie Communionis notio z 1992 r. autorzy zauważają, iż pojęcie komunii znajduje się w samym sercu samorozumienia Kościoła, ,jako Misterium osobowej jedności każdego człowieka z Trójcą Świętą i z innymi ludźmi, zapoczątkowanej przez wiarę i skierowanej do pełni eschatologicznej w Kościele niebieskim, która w pewnej mierze urzeczywistnia się już w Kościele na ziemi”"37.

„Istotą chrześcijańskiego ujęcia komunii jest nade wszystko uznanie jej za dar Boży, za owoc Boskiej inicjatywy, która wypełniła się w Misterium Paschalnym. Nowy związek między człowiekiem i Bogiem, zapoczątkowany w Chrystusie i przekazywany w sakramentach, rozciąga się także na nowy związek ludzi między sobą. $Z$ tego powodu pojęcie komunii musi także wyrażać naturę sakramentalną Kościoła" ${ }^{38}$. Podstawą i środkiem komunii eklezjalnej jest chrzest oraz Eucharystia.

35 Por. R. Marangoni, La chiesa mistero di comunione. Il contributo di Paolo VI nell'elaborazione dell'ecclesiologia di comunione (1963-1978), Roma 2001, 161-551.

36 Por. Relacja końcowa Nadzwyczajnego Synodu Biskupów. Watykan 1985, w: Nadzwyczajny Synod Biskupów. Dwudziestolecie Soboru Watykańskiego II, Wrocław 1986.

37 List o niektórych aspektach Kościoła pojętego jako komunia (Communionis notio), Watykan 1992 , nr 3.

38 Tamże, nr 3. 
To kościelnotwórcze oddziaływanie chrztu i Eucharystii widać wyraźnie w papieskim nauczaniu Jana Pawła II, który w swojej ostatniej encyklice, Ecclesia de Eucharistia, mówi o wspólnocie eucharystycznej. Podobną myśl bez trudności odnajdujemy w spuściźnie Josepha Ratzingera - Benedykta XVI. Także papież Franciszek chętnie sięga po wyrażenie communio, aby opisać Kościół.

Warto też zwrócić uwagę na dokument Międzynarodowej Komisji Mieszanej do Dialogu Teologicznego między Kościołem rzymskokatolickim a Kościołem prawosławnym z 13 października 2007 r. pt. Eklezjologiczne i kanoniczne konsekwencje sakramentalnej natury Kościoła. Communio, soborowość i autorytet. Teologowie obu Kościołów zauważają, iż Eucharystia w świetle tajemnicy trynitarnej stanowi kryterium życia kościelnego.

\section{Chrzest i Eucharystia oznaczają i sprawują kościelną jedność}

Te dwa najważniejsze sakramenty nie tylko zatem inicjują w wierzących życie Boże i ich umacniają w drodze do niebiańskiej ojczyzny, lecz prowadzą ku zbawczemu dialogowi z Trójjedynym Bogiem, który rozpoczyna się już tu na ziemi. Usprawiedliwienie udzielone człowiekowi przez chrzest wprowadza go w komunię z Chrystusem i z Jego braćmi i siostrami, i jest to wspólnota nie tylko duchowa, lecz i na wskroś realna, dzięki Eucharystii.

Jeśli chodzi o zagadnienie ustanowienia sakramentów oraz ich ilość perspektywa katolicka różni się od ewangelickiej. Protestanci stoją na stanowisku, iż potwierdzenie biblijne mają jedynie dwa sakramenty, tj. chrzest i Wieczerza Pańska. Strona katolicka nie poszukuje w Piśmie Świętym uzasadnienia każdego z siedmiu sakramentów, gdyż wyznaje pogląd, iż sakramenty zostały ustanowione w samym założeniu Kościoła, którego opisuje jako sakrament podstawowy. Obie strony spotykają się w chrystocentrycznym nastawieniu, choć inaczej je interpretują odnośnie do sakramentów. Katoliccy przyjmują, iż sakramentalny charakter Kościoła wypływa z tajemnicy Chrystusowej śmierci, zmartwychwstania, uwielbienia i zesłania Ducha Świętego. Trzeba pamiętać, iż w momencie chrztu człowiek otrzymuje nową tożsamość, wiążącą go z tożsamością samego Jezusa. Chrzest zatem sprawia przynależność człowieka do Ducha Świętego. Być ochrzczonym w Duchu Świętym, to otrzymać tożsamość syna bądź córki, któremu (której) zostały odpuszczone wszystkie grzechy. Rozejście obu chrześcijańskich tradycji ma również miejsce odnośnie do rozumienia tradycji i sukcesji apostolskiej. Dla teologii protestanckiej sukcesja apostolska to wierność Słowu Bożemu, natomiast katolicka utrzymuje, iż sukcesja wiary apostolskiej musi łączy się w nieprzerwanej sukcesji urzędu biskupiego. Dlatego katolicy wierzą, iż sukcesja apostolska to konstytutywny element Kościoła, a protestanci mówią 
o co najwyżej pożyteczności znaku sukcesji w urzędzie. W konsekwencji obie strony mają inne podejście do sakramentu Eucharystii ${ }^{39}$.

Rozbieżność stanowisk zachodzi także w kwestii przyczynowości sakramentów. Katolicy opowiadają się za zasadą działania ex opere operato, a ewangelicy utrzymują, iż sprawowany sakrament jako taki nie posiada własnej skuteczności, lecz działa jedynie fides sacramenti. Luter jednak zaznaczył, iż wprawdzie sakramenty są skuteczne dzięki wierze, ale nie wolno twierdzić, iż zawdzięczają swą skuteczność tylko dzięki skuteczności wiary.

Zgodności można się dopatrywać w kwestii rozróżniającej między tworzeniem Kościoła a jego urzeczywistnianiem. Tylko chrzest i Eucharystia są sakramentami, jakie tworzą Kościół. Chrystus jest Tym, który wszczepia do Kościoła przez chrzest i Eucharystię. Natomiast pozostałe sakramenty są eklezjalną aktualizacją. Tak katolicy, jak i ewangelicy - wolno przyjąć - zgodnie utrzymują, iż Kościół zawdzięcza wszystko Chrystusowi nie tylko jako swojemu Założycielowi, ale w Nim jest uzasadnienie całej dynamiki zbawiającej łaski ${ }^{40}$.

Przywołując koncepcję Kościoła i elementy go tworzące w perspektywie ewangelickiej, można przytoczyć analizy ks. prof. Jaskóły, który wykazuje znaczącą rolę Ducha Świętego. Tak we wczesnej teologii reformowanej, jak i w dziewiętnastowiecznej teologii, prezentowanej przykładowo przez F.D. Schleiermachera, czy w dwudziestowiecznej - przez K. Bartha, H. Berkhofa znajdujemy zręby pneumatologii i ich związki z eklezjologią ${ }^{41}$. Barth podkreślając podmiotowość Boga - w przeciwieństwie do Schleiermachera, który uwypuklał podmiotowość człowieka - ujmuje Ducha Świętego jako moc działającą we wspólnocie. Współcześni teologowie ewangeliccy, jak np. E. Jüngel, A. Birmelè, W. Marxsen, J. Moltmann, J. Narzyński, opisują działanie Ducha Świętego przez Chrystusa, przynoszącego człowiekowi usprawiedliwienie, aby przez sakrament chrztu i Wieczerzy Pańskiej utworzyć z wierzących kościelne communio.

Podsumowując należy zauważyć, iż chrzest nie jest czynnością odnoszącą się jedynie do indywidualnego człowieka, ale ma nade wszystko charakter wspólnotowy. Ten sakrament braterskiej jedności - wspólny dla wszystkich Kościołów chrześcijańskich - zobowiązuje ich do wyznawania wiary chrześcijańskiej. Między ochrzczonymi zachodzi wyjątkowa więź: zrodził ich jeden sakrament, uświęcił jeden Duch, łączy jedna wiara. Mogą nazywać się braćmi i siostrami. Wśród współczesnych teologów toczy się dyskusja, czy chrzest

39 Por. R. Porada, Jedność tradycji i sukcesji apostolskiej, „Studia Oecumenica” 2 (2002), 178.

${ }^{40}$ Por. Y. Congar, Kościót jako sakrament zbawienia, 66-77.

${ }^{41}$ Por. P. JASKÓŁA, Panem jest Duch. Zasadnicze kierunki reformowanej pneumatologii, Opole 2000, 17. 
wciela najpierw w Chrystusa, a następnie w społeczność Kościoła, czy dzieje się to odwrotnie ${ }^{42}$.

Rekonstruując kościelnotwórcze działanie chrztu, trzeba wskazać na uprawnienie i zobowiązanie wierzących do czynnego udziału w obrzędach liturgicznych. Chrzest włączając w powszechne kapłaństwo - co podkreślają Kościoły, które wyszły z Reformacji, jak i soborowe nauczanie Kościoła rzymskokatolickiego - skłania wiernych do ofiar duchowych, do służby dla Chrystusa. Wynikiem chrztu jest zobowiązanie do misyjności. Kościół, który nie ewangelizuje, nie jest przecież Kościołem. Dlatego ochrzczeni mają głosić czystą Ewangelię. M. Thurian i Y.P. Emery, przedstawiciele protestanckiej wspólnoty z Taizè podobnie zresztą jak i teologia katolicka - akcentują w ochrzczonym prorocką funkcję Chrystusa. Dlatego chrzest, wprowadzając wiernego w uczestnictwo w funkcji kapłańskiej, królewskiej i prorockiej Chrystusa, jawi się rzeczywiście jako sakrament społeczno-kościelny. Wszystkie Kościoły zauważają zarówno konieczność, jak i niepowtarzalność chrztu. W chrzcie ujawnia się złożona natura mysterium ecclesiae, tak wymiar Boski, jak i ludzki, gdyż łączą się w nim elementy widzialne z niewidzialnymi, a materialne $\mathrm{z}$ duchowymi ${ }^{43}$.

Konsekwencje chrztu dla tworzenia kościelnej wspólnoty w perspektywie katolickiej i ewangelickiej wyraźnie ujawniają dwa znaczące dokumenty w dialogach multilateralnych, a mianowicie: z Akry (1974) oraz z Limy (1982). Ich studium nie zostawia cienia wątpliwości na jednoczącym wymiarze chrztu. Podobnie dokumenty dialogów bilateralnych, jak np. anglikańsko-rzymskokatolickiego (1975), baptystyczno-reformowanego (1977), luterańsko-metodystycznego (1979-1984), anglikańsko-reformowanego, itd. prezentują chrzest jako podstawę kościelnej jedności ${ }^{44}$.

Oczywistym jest także eklezjotwórcza natura Eucharystii. Świadczą o tym nie tylko świadectwa biblijne i patrystyczne, ale cała teologia podzielonego chrześcijaństwa. „Stanowimy jedno ciało, bowiem wszyscy jesteśmy uczestnikami jednego chleba" - przekonuje nas Paweł Apostoł w 1 Kor 10,16-17. Znaczenie Wieczerzy Pańskiej dla tworzenia Kościoła ujawnił już sam Luter, kiedy odmówił kościelności wspólnotom reformowanym, które nie uznały rzeczywistej obecności Chrystusa. Eklezjologiczny charakter Eucharystii ujawniają nie tylko pierwsze spory wewnątrzprotestanckie, ale w sposób pozytywny doszedł do głosu współcześnie - w Konkordii Leuenberskiej zawartej w 1974 r. przez europejskie Kościoły luterańskie, ewangelicko-reformowane, Kościoły przedrefor-

42 Por. W. Hanc, Ekumeniczny wymiar sakramentów chrześcijańskiej inicjacji w świetle międzywyznaniowych dialogów doktrynalnych. Studium ekumeniczne, Włocławek 2003, 308-309.

${ }^{43}$ Por. tamże, 310-312.

${ }^{44}$ Por. tami்e, 314-320. 
macyjne (waldensi, bracia czescy), Kościoły tradycji ewangelicko-unijnej oraz metodystycznej. To przecież w Eucharystii Kościół najpełniej spotyka Chrystusa, który udziela zbawienia jednostkowo i wspólnotowo. To właśnie w Eucharystii wchodzimy we wspólnotę z naszymi braćmi w tajemnicy Kościoła. Warto zaznaczyć przełom, jaki dokonał się w nauce o Kościele pod wpływem prawosławnego teologa N. Afanasjewa (1893-1966) i jego eklezjologii eucharystycznej, co skutkuje w teologii ekumenicznej. Ostatecznie wolno stwierdzić, iż, po pierwsze, Eucharystia jest włączeniem w Mistyczne Ciało Chrystusa, co prowadzi do jedności. Po drugie, jej specyfiką jest społeczność, czyli powiązanie człowieka z Bogiem i ludźmi między sobą. Po trzecie, jest ona ucztą, a przecież uroczystego biesiadowania nikt nie odbywa samotnie. Po czwarte, symbolika obmycia nóg przez Jezusa w Wieczerniku wiąże się z przykazaniem miłości bliźniego i służby każdemu potrzebującemu. Po piąte, $\mathrm{z}$ ofiarą Chrystusa musi się łączyć ofiara wierzącego, aby wypełniał swoją funkcję kapłaństwa powszechnego, zaciągniętego mocą chrztu. Dlatego celebracja Abendmahl domaga się wspólnoty. Po szóste, sprawowanie Eucharystii buduje Kościół lokalny, konsoliduje i scala parafię, gdyż oznacza ona i sprawia jednośćc 45 .

Eklezjotwórczy charakter chrztu i Eucharystii jest uznawany przez wszystkie Kościoły i wspólnoty chrześcijańskie. I mimo iż dochodzi między nimi do różnic w rozumieniu tych dwóch sakramentów oraz rozbieżności w pojmowaniu samego Kościoła i jego sakramentalności, to jednak wszyscy chrześcijanie tak wierzą, jak i widzą, że bez chrztu i Eucharystii nie doznają ani jedności z Chrystusem, ani też między sobą. Zmartwychwstały Pan najpełniej bowiem udziela się wierzącym w swoim Kościele.

\section{Bibliografia}

Appel S., „König Heinz und Junker Jörg”. Heinrich VIII. gegen Luther gegen Rom, Darmstadt 2016.

Artykuły szmalkaldzkie, w: Księgi wyznaniowe Kościoła luterańskiego, Bielsko-

-Biała 1999, s. 335-358. Wersja oryginalna: Schmalkaldische Artikel, w:

BSLK, s. 407-468.

Congar Y., Kościót jako sakrament zbawienia, thum. T. Mazuś, Warszawa 1980.

DenZINGER-SchönMETZER, Enchiridion symbolorum, definitionum et declaratio-

num de rebus fidei et morum, Barcelona - Freiburg im Br. - Rom 1976 ${ }^{36}$.

DörIng H., Grundriß der Ekklesiologie, Darmstadt 1986.

Eмme D., Martin Luter. Seine Jugend- und Studienzeit, Regensburg 1981.

\footnotetext{
${ }^{45}$ Por. W. Hanc, Ekumeniczny wymiar sakramentów chrześcijańskiej inicjacji, 324-337.
} 
ERIKSON E.H., Der junge Mann Luther. Eine psychoanalitische und historische Studie, Frankfurt am M. 1975.

Grane L., Wyznanie augsburskie. Wprowadzenie w podstawowe myśli Reformacji luterańskiej, tłum. K. Lazar, J.T. Maciuszko, Bielsko-Biała 2002.

HANC W., Ekumeniczny wymiar sakramentów chrześcijańskiej inicjacji w świetle międzywyznaniowych dialogów doktrynalnych. Studium ekumeniczne, Włocławek 2003.

JaskóŁa P., Panem jest Duch. Zasadnicze kierunki reformowanej pneumatologii, Opole 2000.

JASKÓŁA P., Problem małżeństwa $w$ relacjach ewangelicko-rzymskokatolickich. Historia i perspektywy nowych rozwiazań, Opole 2013.

JASKÓŁA P., Usprawiedliwienie $i$ uświęcenie wedtug Jana Kalwina, w: TENŻE (red.). Ekumenizm na progu Trzeciego Tysiaclecia, Opole 2000, s. 297-309. JASKÓŁA P., Wyznania chrześcijańskie bez jedności z Rzymem, Opole 2008.

KopIEC P., Eschatologia anglikańska, „Roczniki Teologii Ekumenicznej” 3 (2011), s. 133-149.

KopIEC P., Instytucja matzeństwa a sakramentologia luterańska, ,Roczniki Teologiczne" 55 (2008) 7, s. 174-186.

Księgi wyznaniowe Kościoła luterańskiego, Bielsko-Biała 1999.

LAu F., Marcin Luter, tłum. J. Narzyński, Warszawa 1966.

List o niektórych aspektach Kościoła pojętego jako komunia (Communionis notio), Watykan 1992.

Marangoni R., La chiesa mistero di comunione. Il contributo di Paolo VI nell'elaborazione dell'ecclesiologia di comunione (1963-1978), Roma 2001.

NAPIóRKowsKi A.A., Bogactwo łaski a nędza grzesznika. Zróżnicowany konsensus teologii katolickiej i luterańskiej o usprawiedliwieniu osiagnięty w dialogu ekumenicznym, Kraków $2011^{2}$.

NapióRKowski A.A., Bosko-ludzka wspólnota. Podstawy katolickiej eklezjologii integralnej, Kraków 2010.

NAPIóRKowsKi A.A., Usprawiedliwienie grzesznika, Kraków 1998.

Obrona Wyznania Augsburskiego, w: Księgi wyznaniowe Kościoła luterańskiego, Bielsko-Biała 1999, s. 165-325. Wersja oryginalna: Apologia Confessionis Augustanae, w: BSLK, s. 139-404.

Podzielny J., Godność powołania małżeńskiego w ujęciu Marcina Lutra, „Studia Oecumenica" 9 (2009), s. 151-157.

Porada R., Jedność tradycji i sukcesji apostolskiej, „Studia Oecumenica” 2 (2002), s. 178-194.

Porada R., Kościół i apostolskość Kościoła w nauczaniu Marcina Lutra, „Studia Oecumenica" 1 (2001), s. 173-186. 
Relacja końcowa Nadzwyczajnego Synodu Biskupów. Watykan 1985, w: Nadzwyczajny Synod Biskupów. Dwudziestolecie Soboru Watykańskiego II, Wrocław 1986.

Schilling H., Marcin Luter. Buntownik w czasach przełomu, tłum. J. Kałążny, Poznań 2016.

Sauter G., Podstawowe pytania wiary, Bielsko-Biała 1997.

Uglonz M., Marcin Luter. Ojciec Reformacji, Bielsko-Biała 1995.

Uglorz M., Zarys nauki Kościoła luterańskiego, w: J. Below, M. Legendź (red.), Świadectwo wiary i życia. Kościół luterański w Polsce wczoraj i dziś, Bielsko-Biała 2004, s. 7-51.

Wyznanie Augsburskie (Konfesja Augsburska), w: Księgi wyznaniowe Kościoła luterańskiego, Bielsko-Biała 1999, s. 143-163. Wersja oryginalna: Confessio Augustana (Augsburger Bekenntnis), w: BSLK, s. 31-137. 